\title{
Corporations' Choice of Tax Regime when Transition Costs are Small and Income Shifting Potential is Large
}

\author{
ANNETTE ALSTADSÆTER \\ KNUT REIDAR WANGEN
}

CESIFO WORKING PAPER NO. 2392

CATEGORY 1: PUBLIC FinANCE

SEPTEMBER 2008
An electronic version of the paper may be downloaded
- from the SSRN website: Www.SSRN.com
- from the RePEc website: Www.RePEc.org
- from the CESifo website: www.CESifo-group.org/wp




\title{
Corporations' Choice of Tax Regime when Transition Costs are Small and Income Shifting Potential is Large
}

\begin{abstract}
The literature provides ambiguous results on the effect of taxes on businesses' choice of organizational form, partly due to a lack of good firm-level data. Our micro data covers the full population of non-financial Norwegian corporations over ten years. During this period, the dual income tax system allowed corporations to shift tax regime without changing organizational form. We show that the income shifting potential is large for the active owners of a corporation that participate in a tax reducing coalition. Our results show that corporations respond to tax incentives and change tax regime in order to reduce tax payments. But persistent cohort effects in the choice of tax regime and substantial unobserved corporationspecific effects indicate that non-tax factors matter as well. Corporations founded prior to the introduction of the dual income tax differ substantially from those founded after in their adaptation to the incentives for shifting tax regime.
\end{abstract}

JEL Code: D21, H25, H3.

Keywords: corporate taxation, choice of tax regime, tax minimization.

\author{
Annette Alstadsceter \\ Institute of Health Management and \\ Health Economics \\ PO Box 1089 Blindern \\ University of Oslo \\ Norway-0317 Oslo \\ annette.alstadsater@medisin.uio.no
}

\author{
Knut Reidar Wangen \\ Institute of Health Management and \\ Health Economics \\ PO Box 1089 Blindern \\ University of Oslo \\ Norway - 0317 Oslo \\ k.r.wangen@medisin.uio.no
}

This version: August 17, 2008.

Comments from participants at the IIPF conference in Warwick in 2007, in particular Johannes Becker, and participants at a seminar at the University of Stavanger are appreciated. Alstadsæter benefited greatly from a research stay at Center for Economic Studies at University of Munich. We are grateful for grant 158143/S20 from the Research Council of Norway. 


\section{Introduction}

We have seen numerous base broadening and rate cutting tax reforms over the last 20 years. At the same time, the importance of corporations in the economy has increased in several countries, as shown by Weichenrieder (2005) and Sørensen (2007). Following Gordon and Slemrod (2000), what might seem as increased business activity through an increasing number of corporations could in fact be the result of tax reducing income shifting between the personal and corporate tax bases. Such new corporations can be the result of tax induced shift in organizational form of already existing businesses. In some cases, firms are established with the sole purpose of reducing tax payments of the owners. Income shifting through the choice of organizational form is studied empirically by Gordon and MacKie-Mason (1994), Gentry (1994), Ayers et al. (1996), MacKie-Mason and Gordon (1997), Goolsbee (1998, 2004), Romanov (2006), Mooij and Nicodème (2008), and Thoresen and Alstadsæter (2008), and the conclusions are ambiguous, as discussed in section 2.

Under the Norwegian dual income tax system of 1992-2005, corporations could be taxed according to two different tax regimes, depending on ownership constellations. ${ }^{1}$ Corporations could shift tax regime at almost no transaction costs and without affecting the relationship to creditors and employees. In contrast, a shift between liable and non-liable organizational form may incur transition costs. We analyze the full population of Norwegian corporations over the period 1993-2002; a rich panel data set extracted from administrative registers with more than 800,000 observations of more than 140,000 corporations over a period of 10 years. Instead of studying the effects of a tax reform on a firm's preferred choice of organizational form, we evaluate the dynamic adaption to an existing tax system.

Our results show that corporations respond to tax incentives and change tax regime in order to reduce tax payments. But even in our setting, with minimal transition costs of changing tax regime, it seems like non-tax factors matter for the choice of tax status. Corporation-specific effects are substantial. We also find that corporations founded prior to the 1992 tax reform differ systematically from corporations founded after the reform. This suggests that post-reform corporations were more able to form tax reducing coalitions, compared to pre-reform corporations.

\footnotetext{
${ }^{1}$ In 2006, a dividend tax was introduced, and all corporations were then taxed according to the same tax regime. See Sørensen (2005) for more on this.
} 
We also find that the probability of choosing a given tax regime is state dependent, in the sense that this probability is clearly depending on the tax regime chosen in the previous year.

Three contributions are likely to be applicable in more general cases. First; we provide a practical theoretical framework for the analysis of tax induces income shifting. We define terms such as tax reducing coalition, income shifting potential, and tax regime potential. Second; we find evidence that suggest that corporations founded prior to the 1992 reform have adapted systematically less well to the tax system, compared to corporations founded after the reform. This may imply that it will not be sufficient to observe a two-wave panel, with one pre-reform wave and one post-reform wave, in order to measure the quantitative effects of a reform; Cohort effects are persistent several years after the reform. And third; previous empirical studies, usually based on short panels or cross sections, often use the log-transformation of variables with skew distributions (such as assets, profits, or number of employees), at the cost of excluding observations with zero values or having to treat sub-samples with positive and negative values separately. In long panels such practices become impractical, since a given corporation in some periods belongs to one sub-sample and in other periods belongs to another. We overcome these obstacles by applying a simple Inverse Hyperbolic Sine (IHS) transformation that reduce the influence of extreme values, positive as well as negative, and allows the inclusion of observations with zero values.

\section{Background}

\subsection{The Literature}

An early empirical study of the effect of taxes on organizational form was conducted by Ayers et al. (1996). The study was based on data from the U.S. in the period 1988-1989, following the 1986 tax reform, and found weak support to the hypothesis that taxes affect businesses' choice of organizational form, while state non-tax factors seemed to dominate the choice. Gentry (1994), also on U.S. data, finds that business risk is an important determinant for the choice of organizational form with differences in both liability and tax legislation. Based on aggregated shares of businesses in the corporate form for the U.S. in the period 1959-1986, MacKie-Mason and 
Gordon (1997) finds relatively small tax effects on the choice of the corporate and non-corporate organizational forms. This latter approach is replicated by Goolsbee (1998) on U.S. data in the period 1900-1939, and the results indicate a small impact of taxes. Goolsbee (2004) uses the same approach as Gordon and MacKie-Mason (1994) on U.S. state level data for 1992. He has data on a large number of firms in the retail industry across U.S. states, which provides him with more variation in tax rates. He finds a large effect of taxes on the choice of organizational form.

In recent years, some contributions have been made on data from countries other than the U.S.A. Romanov (2006) states that two changes of the Israeli dual income tax regime spurred high-income professionals in certain industries to shift out of paid employment and instead form one-man corporations in order to reduce tax payments. Mooij and Nicodème (2008) analyze panel data from 17 European countries and conclude that there is substantial income shifting from the personal to the corporate tax base through the choice of firms' organizational form. They suggest that $12 \%$ $21 \%$ of corporate tax revenue may come from income shifting. Pirttilä and Selin (2006) document an increase in taxable capital income of the Finnish self-employed individuals after the introduction of dual income tax, interpreted as tax reducing income shifting to the capital income tax base by the self-employed individuals. Thoresen and Alstadsæter (2008) find that owners of small Norwegian firms that shifted into the widely held corporate form had higher income growth than those that remained in self-employment or as a closely held corporation.

Two theoretical contributions on the choice of organizational form under the dual income tax are Lindhe et al. (2004) and Alstadsæter (2007), and they provide overview over the different countries' income splitting rules. The effects of the dual income tax on related issues as taxable income, demand for debt and tax progressivity are studied by Aarbu and Thoresen (2001), Fjærli (2004), Fjærli and Lund (2001), Thoresen (2004), and Lambert and Thoresen (2008) on Norwegian data. Similar studies are conducted on Swedish data by Selén (2002) and Hansson (2004). Kari et al. (2008) studies the effects of an introduction of a Finnish dividend tax on the financial policies of firms operating under a dual income tax regime. 


\subsection{Details on the Norwegian tax system in the period 1992- 2004}

The Norwegian tax system in the period 1992-2005 was a dual income tax system that levied separate tax schedules on income from labor and capital. ${ }^{2}$ It combined a low proportional tax rate on capital income with a progressive tax rate on labor income. The corporate tax rate was the same as the capital income tax rate, and there was no tax on dividends. Thus, for individuals in medium and high income classes, there was a substantial difference in the marginal tax rates on capital and labor income. At its peak, the difference in the top marginal tax rates on capital and labor was 27.3 percentage points. This provided large incentives for income shifting from labor income to capital income. As a countermeasure towards such income shifting from the personal to the corporate tax base, the corporate tax system included a system for imputing - for tax purposes only - the return to capital and labor effort of the owners in corporations.

Thus, the Norwegian corporate tax system consisted of two distinct tax systems, which we will refer to as the widely held regime and the closely held regime. A corporation was defined as closely held if $2 / 3$ or more of the shares were held by active owners. An owner was defined as active if he worked more than 300 hours annually in the corporation, and defined as passive otherwise. ${ }^{3}$ A corporation was defined as widely held if less than $2 / 3$ of the shares were held by active owners. For widely held corporations, profits were taxed at the proportional tax rate and dividends to owners were tax exempt. The same rules applied to closely held corporations, but in addition an imputed return to labor was calculated and added to the active owners' labor income tax base. The imputed return to labor was business profits net of imputed return to labor in the corporation, up to a threshold, and net of a salary deduction. ${ }^{4}$ The imputed return to capital was calculated by multiplying the value of the capital assets by a fixed rate of return on capital, which during the period varied from $10 \%$ to $16 \%$. If imputed labor income was negative, the loss did not offset other income;

\footnotetext{
${ }^{2}$ For further details on the dual income tax, see Sørensen $(1994,2005)$ and Lindhe et al. (2004).

${ }^{3}$ If active owners transferred ownership to their (passive) spouses or under-aged children, the tax authorities would still regard the ownership as an active one.

${ }^{4}$ The salary deduction was for the broader part of the period $20 \%$ of the corporation's total wage costs.
} 
it could be carried forward and deducted against future imputed labor income in the same firm. The imputed return to labor was taxable regardless of whether or not the owners had received payment from the corporations. Employers' social security contributions (the payroll tax) apply to all wage payments made by the corporation. The contribution varies from 14.1 percent to zero according to regional zones.

\section{Income shifting potential, tax regime shifting potential, and tax reducing coalitions}

Consider a corporation with concentrated ownership that generates a given annual profit. How can the owners receive the most of this profit, after taxes? This is a simultaneous tax minimization problem of income shifting and choice of tax regime. Let us divide this into different subproblems: First, for each tax regime, which is the optimal wage-dividend scheme to the owners? Second, given the optimal solutions for both tax regimes, which is the optimal regime? In this approach it is useful to decompose the overall potential gain from these tax minimizing activities into income shifting potential and the tax regime shifting potential. These concepts can be compared with the more familiar concept of potential Pareto improvements, where a policy change that makes the society as a whole better off can be considered as a Pareto improvement as long as the individuals who gain can compensate the ones who lose through a cash transfer.

To fix ideas, suppose the corporation is operating under the closely held tax regime. The total payable tax will depend (among other things) on how much of profits are distributed as dividends, on how much is paid as wage compensation to the owners, and on their individual tax rates on labor income. If the owners simply decide to pay wage compensation according to each owner's actual labor effort, and let the resulting profits be distributed as dividends according to ownership shares, there will usually be left a potential Pareto improvement: If the owners agreed on a different wage-dividend scheme, the group as a whole could be made better off; and if they can agree on side-payments, they may all be made better off. Similarly, the owners could, in principle, choose a wage-dividend scheme that made them worse off. The difference between the best and the worst scheme within a tax regime, 
measured in after tax income, is what we define as the income shifting potential. ${ }^{5}$

Similarly, the owners could find the optimal wage-dividend scheme under the widely held regime. The difference between optimal solutions in the two tax regimes is what we define as tax regime shifting potential. If the tax regime shifting potential is non-zero, and the corporation is currently operating under the least favorable regime, there exists potential Pareto improvements: An agreement, with side payments, between active and passive owners could make all parties better off.

Let us refer to this type of coalition of owners as tax reducing coalitions. The income shifting potential and regime shifting potential of a tax reducing coalition exist even though they for various reason are not realizable. These are pure theoretical concepts intended to show how great the incentives for participating in tax reducing activities are.

There are several examples of such tax reducing coalitions, where both legal and illegal means are used to distribute tax savings amongst the participants. First, if the passive owners are the active owner's children over the age of 18, dividend payments to passive owners will be tax exempt transfers within the family. The active owner will then internalize this as his own income and automatically choose the optimal wage-dividend scheme for the coalition. Second, two business owners with similar income potential may swap ownership shares and be passive owners in each other's corporations in order to be classified as widely held corporations. Third, a corporation may have pro-forma passive owners, where only part or none of reported dividends are actually payed.

\subsection{A stylized description of the two Norwegian tax regimes}

In order to illustrate the income shifting incentives inherent under the Norwegian dual income tax, we will now outline the main features in the two tax regimes in a highly stylized situation. Later we use numerical examples to show how large these income shifting incentives can be.

\footnotetext{
${ }^{5} \mathrm{~A}$ related phenomena is documented by Fjærli and Lund (2001). They analyze how owners of corporations choose to pay wages and dividends during a transition period into the dual income tax in Norway. They conclude that owners pay themselves more wages than optimal from a short term tax reducing view, and suggest that this can be optimal from a long-term view, as wage payments are the basis for future pension benefits.
} 
Consider a corporation that is operative in a single year only, that has just one active owner, and potential passive owners so that it is able to choose tax regime. In order to focus on the income shifting aspect, we abstract from any real decisions, such as production levels, investments, number of employees. We also abstract from ownership composition and the price of their ownership shares that the passive owners have to pay. The main objective is to show how much the tax reducing coalition as a whole may save in taxes by engaging in the tax reducing activities outlined above. How they then distribute their income amongst themselves is uninteresting in this context. The advantage is that we only use variables that are fully observable for the tax authorities.

Assume that there is a fixed net revenue in the corporation that is to be distributed to the active and passive owners in the coalition, either as wages to the active owner, $W$, or dividends, $D$, to all owners. The main objective is to maximize total after-tax income of the coalition as a whole. Any conflict of interest between active and passive owners are disregarded, or assumed perfectly solvable by side payments. The after-tax income of the coalition as a whole is denoted $Y$, and is defined by

$$
Y=W+D-\left[T_{w}(W+I)-t_{c} I\right]
$$

where the expression in the brackets constitutes the payable personal taxes of the coalition. Here, $T_{w}($.$) - a piecewise linear, non-decreasing and continuous function$ - is the tax amount payable of the sum of wages and imputed return to labor, $I$, and $t_{c}$ is the flat capital tax rate. The imputed return to labor is only computed by the tax authorities, not actually received by the individual. It is part of taxable profits in the corporation. Thus, when labor income taxes due on imputed return to labor on the personal are calculated, taxes paid on the corporate level $t_{c} I$, are deducted. This is also clear from equation (4). Dividends are tax exempt on the owners' hands.

The after tax-income depends on both how the corporate income is distributed to its owner, and the tax regime. We will illuminate this by showing that $D$ and $I$ can be replaced by simple functions of $W$. An intermediate definition of profits is useful, since profits affect both dividends and imputed return to labor. In this context we therefore define the profit of the corporation, $\pi$, as

$$
\pi=R-\left(1+t_{p}\right) W, \quad \pi \geq 0, \quad R \geq 0
$$


where $R$ is a fixed value of net revenue (total revenue less all costs other than owner's wage compensation), and $t_{p}$ is the payroll tax rate. In general, positive profits are taxed at the flat rate $t_{c}$. The restriction requiring non-negative profits imposes an upper bound on the owner's wage compensation, $\bar{W}$, thus the admitted interval for $W$ is:

$$
0 \leq W \leq \bar{W} \equiv \frac{R}{1+t_{p}}
$$

In our setup all profits are distributed as dividends, $D$, which in turn can be considered as a function of wages:

$$
D=\left(1-t_{c}\right) \pi=\left(1-t_{c}\right)\left(R-\left(1+t_{p}\right) W\right), \quad D \geq 0
$$

The main difference between the closely held and the widely held tax regimes is the imputed return to labor:

$$
I= \begin{cases}0, & \text { if widely held } \\ \max \left[0, \pi-I_{0}-s W\right]=\max \left[0, R-I_{0}-\left(1+t_{p}+s\right) W\right], & \text { if closely held }\end{cases}
$$

where $I_{0}$ is deductions due to imputed return to capital or salaries to employees other than the active owner, and $s$ is the salary deduction factor. ${ }^{6}$ In our one-year setup, negative values of imputed return to labor will be disregarded, and only positive values will influence the active owner's after tax income.

Inserting for $I$ and $D$ in (1) we obtain expressions for the after tax income as a function of the active owner's wage compensation. In both tax regimes the after tax income is a piecewise continuous function of $W$. In order to maximize after tax income we need to check the end-point of the admitted interval for $W$ and all point where either of the tax regime-specific functions have a kink.

\subsection{Illustration by numerical examples}

The main features of the Norwegian tax system can more easily be illustrated if we impose a simplifying assumption: we disregard the progressive structure of the

\footnotetext{
${ }^{6} \mathrm{It}$ is possible to increase $I_{0}$ by increase the capital stock of the corporation, as described in Alstadsæter (2007). But as the stock of capital is disregarded in this stylized model, that will not be an issue here.
} 
actual tax system and assume that there is a fixed tax rate on labor income. This is expressed as $T_{w}=t_{w} \cdot(W+I)$, where $t_{w} \geq t_{c}$ is the constant tax rate. In this case the after tax income for widely held corporations can be written as

$$
Y_{w h}(W)=\left(1-t_{c}\right) R+\left(\left(1-t_{w}\right)-\left(1-t_{c}\right)\left(1+t_{p}\right)\right) W, \quad W \geq 0
$$

which is a simple linear function. For closely held corporations the after tax income can be written as

$$
Y_{c h}(W)= \begin{cases}Y_{w h}(W)-\left(t_{w}-t_{c}\right)\left(R-I_{0}-\left(1+t_{p}+s\right) W\right), & \text { if } 0 \leq W \leq \widehat{W} \\ Y_{w h}(W), & \text { if } W \geq \widehat{W}\end{cases}
$$

where $\widehat{W}=\left(R-I_{0}\right) /\left(1+t_{p}+s\right)$. This function is piecewise linear with a kink for $W=\widehat{W}$. It follows from the assumptions that $Y_{w h}(0) \geq Y_{c h}(0)$.

We first turn our attention to the income shifting potential. The derivatives with respect to $W$ is useful for this purpose. For a widely held corporations the derivative is

$$
Y_{w h}^{\prime}(W)=-\left(t_{w}-t_{c}\right)-t_{p}\left(1-t_{c}\right), \quad W \geq 0,
$$

which implies that $Y_{w h}(0) \geq Y_{w h}(\bar{W})$. For a tax reducing coalition of owners of a widely held corporation, it is optimal to pay zero wage to the active owner and instead paying all profits as dividends. For a closely held corporation, the kink introduces a slight complication:

$$
Y_{c h}^{\prime}(W)= \begin{cases}\left(t_{w}-t_{c}\right)-t_{p}\left(1-t_{w}\right), & \text { if } 0 \leq W \leq \widehat{W} \\ Y_{w h}^{\prime}(W), & \text { if } W \geq \widehat{W}\end{cases}
$$

The derivative for closely held corporations can be positive for $W \leq \widehat{W}$, which implies that $Y_{c h}(\widehat{W})$ is the maximum; otherwise $Y_{c h}(0)$ is the maximum.

After finding the income shifting potential for each tax regime, we can then calculate the tax regime shifting potential by comparing the maximum after tax income across tax regimes. We will refer to Table 1 to illustrate. Since this table is only intended for illustration purposes, the net revenue (before taxes and wage payments to the active owner) is normalized to 100 .

The left column of Table 1 lists the endpoints and kink-point for a corporation with $I_{0}=0$, which we can interpret at single-person corporation without capital stock or employees. If this corporation is widely held and the owner's wage is set to zero, the after tax income will be 72 , while if it set to its highest possible value 
Table 1: Numerical examples, eq. (6) and (7) for owners in high tax brackets. $R=$ $100, t_{c}=0.28, s=0.20, t_{w}=0.55, t_{p}=0.141$

\begin{tabular}{lrr}
\hline & $I_{0}=0$ & $I_{0}=90$ \\
\hline$Y_{w h}(0)$ & 72.0 & 72.0 \\
$Y_{c h}(0)$ & 45.0 & 69.3 \\
$Y_{w h}(\widehat{W})=Y_{c h}(\widehat{W})$ & 44.3 & 69.2 \\
$Y_{w h}(\bar{W})=Y_{c h}(\bar{W})$ & 39.4 & 39.4 \\
\hline Inc.shift.potential, WH & 32.6 & 32.6 \\
Inc.shift.potential, CH & 5.6 & 29.9 \\
\hline Tax reg. shift potential & 27.0 & 2.7 \\
\hline
\end{tabular}

$(\bar{W})$, the after tax income will be only 39.4. This means that the income shifting potential is 32.6 under the widely held tax regime. In the closely held tax regime, the income shifting potential is 5.6; the difference between the maximum value 45.0, obtained when the owner's wage is zero, and the minimum value 39.4, obtained when the owner's wage is at its highest value $(\bar{W})$. The tax regime shifting potential is thus 27.0, which is the difference between the maximum after tax income under the widely held regime (72.0) and the maximum under the closely held regime (45.0).

The deductions due to imputed return to labor or salaries to employees other than the active owner, $I_{0}$, plays an important role. In the right column in Table 1 we have set $I_{0}$ to 90 , which can be interpreted as representing a corporation with large capital stock or with several employees. Under the widely held tax regime, the income shifting potential is unaffected by this deduction, but under the closely held regime the income shifting potential has increased to 29.9. The tax regime shifting potential is reduced correspondingly, to 2.7 .

In this case the income shifting potential is large in both tax regimes, and the tax regime potential is very low. Similar results are found by Thoresen and Alstadsæter (2008).

The size of the pay-roll tax (within the admitted interval between 0 and 14,1\%) can be shown to have little effect on both the income shifting potential and the tax regime shifting potential. But the size of the marginal tax rate on labor income of the active owner in the coalition has a great impact of the results. Both the income shifting and the regime shifting potentials decrease as the marginal tax rate on labor income is reduced. And this is what one would expect, as it is the difference in the 
marginal tax rates on labor and capital that drives this income shifting activity.

These are extreme results in a highly stylized model. In real life there will be conflict of interest between the active and passive owners in the coalition, as wage payments to the active owner will be considered a cost by the passive owners, and dividend payments to passive owners are considered a cost by the active owner. So the actual potential tax savings are smaller in real life, but still expected to be considerable.

\section{Data and data transformations}

Our main data source is the Corporate Accounting Register, which covers all nonfinancial Norwegian corporations. This register provides detailed information on profits, equity, debt, capital, production costs, dividend payments, region and sector. The second important source is the Tax Register, which provides information on imputed return to labor - information that is necessary in order to identify which corporations that are widely or closely held. In the two first years, 1993 and 1994, and to a smaller degree 1995, a substantial share of the firms lack identification numbers and these were excluded from the analysis.

We included only observations where the tax regime in the previous year was observed, we discarded corporations not operating within the seven largest industries, and we excluded observations with missing variables. Starting with 1,160,000 observations with valid identity numbers, these selection rules left us with more than 816,000 observations for more than 143,000 corporations over a period of 10 years.

\subsection{Definition of variables}

The variables Profits and Assets are defined according to general accounting principles and not the current tax code. Corporations are in tax position if Profits are positive. Losses in previous years are deductible and reported values are net values, after deduction of losses carried forward. Assets is used as a proxy to the actual base for calculating imputed return to capital, as this is not available in the data.

The Payroll zone dummies divides all municipalities into five different groups, depending on the rate of payroll tax applicable in the municipality. The payroll tax 
rates varies from $14.8 \%$ (PAYROLL-1) to zero (PAYROLL-5). The highest rates are imposed on relatively economically well-functioning city-like regions, while the lower rates apply to less densely populated areas. Thus, these dummies can be regarded also as measures of the degree of centrality for a firm's location. Data on the rates are obtained from official sources and merged with the register data using municipality numbers.

Labor is the number of full-time equivalent employees. Foundation year is the year the corporation was formed. Note that for firms established as liable and later incorporated, these dummies measures the year of incorporation, and not the year of foundation. For the years 1993-1998, the foundation year is not fully available on the original year-by-year files. For corporations observed in later years, we have imputed missing foundation years based on information available in the full panel.

Industry dummies are defined using official definitions, in accordance to Eurostat's NACE-standard.

\subsection{Transformation of variables}

Models with discrete dependent variables are in general sensitive toward observations with extreme values of the independent variables. Several strategies can be chosen to avoid problems stemming from highly influential extreme values, such as deleting or manipulating the observations identified as problematic, or, as in the present study, by transforming variables so that the distribution of all observations have a lesser spread than the untransformed.

We have chosen to transform the variables Profits, Assets, and Labor by using an Inverse Hyperbolic Sine (IHS) transformation (Johnson, 1949; Burbidge et al., 1988):

$$
g(x)=\ln \left(x+\sqrt{x^{2}+1}\right)
$$

where $x$ denote an untransformed variable. This is a pragmatic choice. The main reason is that, for the three variables in question, there are substantial numbers of observations that take negative values or equals zero. The IHS-transformation can handle any real number. In contrast, the more familiar log transformation cannot handle non-positive values, while the Box-Cox transformation cannot handle zero values (see Burbidge et al., 1988, for a more detailed comparison of these alternative transformations). The IHS-transformation is monotonically increasing, symmetric 
around zero, since $g(x)=-g(-x)$, and converge toward $\ln (2|x|)$ for large values of $|x|$.

The usefulness of the IHS transformation can be illustrated by the profits variable: the distribution is shown in figure 1. A similar figure for the untransformed profits yielded rather useless histograms with low resolution, due to the corporations with large absolute values of profits. Applying the familiar log transformation would require separate treatment of positive values, zeros, and negative values.

\section{Logit models for the choice of tax regime}

We present three different logit models for the choice of tax regime. Model 1 is a pooled model where the panel aspect is disregarded, while model 2 and 3 are random effect logit models.

The three models will be presented in subsections $5.1-5.3$ where we discuss the influence of profits and corporation specific effects on the probability of being closely held. In subsequent subsections discuss the influence of other explanatory factor for all three models simultaneously.

All three models can be described in a common setup for the choice probabilities:

$$
\begin{aligned}
P\left(y_{i t}=0\right) & =\frac{1}{1+\exp \left(z_{i t}\right)} \quad \text { if widely held, } \\
P\left(y_{i t}=1\right) & =\frac{\exp \left(z_{i t}\right)}{1+\exp \left(z_{i t}\right)} \quad \text { if closely held, } \\
\text { where } z_{i t} & =x_{i t} \beta+\nu_{i} .
\end{aligned}
$$

Here $y_{i t}$, equal to either zero or one, denote the observed choice of tax regime for corporation $i$ in observation year $t$. The regression part, $z_{i t}$, consists of a vector of observable regressors, $x_{i t}$, a vector of coefficients, $\beta$, and a corporation specific unobserved effect, $\nu_{i}$. The list of regressors includes linear, quadratic and cross product terms for profits, assets and number of employees, in addition to payroll tax zone-, cohort-, time- and industry dummies - see Tables $2-4$ for details. The corporation specific effects capture unobserved time-invariant variables that affect a specific corporation's choice of tax regime: In Model 1 these effects are disregarded, while in the estimations of Model 2 and 3 the $\nu_{i}$ 's are assumed to be normally distributed,

$$
\nu_{i} \sim i i d N\left(0, \sigma_{\nu}^{2}\right)
$$


and stochastically independent of the observable regressors.

\subsection{Pooled logit: Model 1}

The estimation results for the pooled model, in which the panel data aspect of the data is disregarded, are reported in Table 3.

The coefficient for the squared values of IHS-transformed profits, $(\text { PROFITS })^{2}$, is negative. This suggest that a the share of closely held corporations, conditional on the other regressors, have a maximum and that deviations in profits from this maximum reduces the probability of being closely held. As a general tendency this is in accordance with the descriptive statistics given in Figure $1 \mathrm{~b}$.

The quadratic and cross product terms in the vector of regressors complicate the interpretation of the estimated parameters. For this reason we have included a graphs indicating the effect of profits on the estimated probability of being closely held, see Figure 2. The left part of Figure 2 shows the predicted probability as a function of transformed profits (PROFITS). In the chosen interval for the graph, this function resembles a quadratic function with a single maximum and a symmetrical shape. The right hand side of Figure 2 depicts the same functional relationship, but in terms of untransformed profits (in $1000 \mathrm{NOK}$ ) and for positive profits only. The graphs in Figure 2 indicate that large numerical values of profits have a tendency to reduce the probability of choosing the closely held tax regime. Albeit all estimated coefficients related to profits are statistically significant, cf. Table 3, the effect of profits on choice of tax regime is rather weak.

\subsection{Static random effect logit: Model 2}

In contrast to Model 1, which treats all observations as if they were drawn independently, Model 2 accounts for individual heterogeneity by including corporation specific effects. These effects accounts for unobserved factors that that are fixed (or changes little) during the years a corporation is included in the sample, such as geographical location, and characteristics of the owners - say family or business network that may affect the potential for forming tax reducing coalitions.

From Table 4 we find that the estimated standard deviation of the corporation specific effects, $\sigma_{\nu}$, is 4.5664 . This means that the corporation specific effects are 
likely to be the single most important explanatory factor in Model 2. Figure 3 includes graphs for both Model 2 and Model 3, assuming that $\nu_{i}=0$ but otherwise corresponding to the graphs for the pooled model presented in Figure 2. We will comment on the graphs for Model 3 in the next subsection, but for now they can serve the purpose of illustrating the influence of the corporation specific effects. Suppose we instead of setting $\nu_{i}=0$, we instead used the two values $\nu_{i}=\sigma_{\nu}$ and $\nu_{i}=-\sigma_{\nu}$. Then the two resulting graphs would have been further apart than the two graphs from Model 3 in Figure 3. This suggests that unobserved heterogeneity is a highly influential explanatory factor.

Somewhat surprisingly, the estimated coefficient for $(\text { PROFITS })^{2}$ is positive, suggesting that the probability for choosing the closely held tax regime has a minimum point. In the graph in Figure 3 the minimum value is in the interval $(-3,-2)$. We will point out that even though this seems to contradict the results for Model 1 (and, as we will see later, also Model 3), this result is likely to be an artifact of our model setup: The share of corporations choosing the closely held tax regime follow neither a monotonic nor a quadratic pattern exactly, cf. Figure 1b. When we impose a quadratic structure on this data, we must regard this as a simplifying approximation. When we compare the graphs for Model 1 and Model 2 and view them as predictions of probability levels, they seem relatively similar despite their different curvatures.

\subsection{Dynamic random effect logit: Model 3}

Models 1 and 2 are, formally, static models in the sense that previous choices tax regime or previous values of the regressors are disregarded. The fact that most corporations in the sample choose the same tax regime in all years or change regime at most one time, suggests that observations of past choices is a strong predictor of the current choice.

In Model 3 we have included a dummy indicating the choice of tax regime in the previous year $\left(y_{i, t-1}\right)$. Including this explanatory variable have a striking influence on the estimate for $\sigma_{\nu}$, which is only 0.19 (compared to 4.57 in Model 2). The lost influence of the corporation specific effects are instead captured by the coefficient for tax regime in the previous period. Its value, 4.5053, has a substantial influence on the prediction of the probability of being closely held: In Figure 3, the only difference 
between the two graphs for Model 3 is the value of tax regime in the previous period.

\subsection{Cohort effects}

The choice of tax regime varies systematically between corporations founded in different years. Figure 4 shows the share of closely held corporations for four different cohorts, and how these shares develop over the observation period. The graphs for two cohorts founded prior to the reform (1987 and 1989) are clearly below the two cohorts founded after the 1992-reform (1993 and 1995). For all cohorts the share of closely held corporations decreases from 1994 to 1999 and then flattens out.

There are at least two explanations for this. First, there has been an influx of already established firms who incorporate in order to avoid the split model. Second, newly established firms are more able to form tax reducing coalitions, while existing firms have to do with the existing owners.

In the three logit models, cohort dummies for the years 1986-2001 are included. This means that all cohort effects are measured relative to the group of corporations founded in the year 1985 or earlier. In all three models there is a tendency that the cohort effects shifts in coefficient value, and/or z-ratio at the time of the 1992 tax reform: Pre-reform effects tend to be either positive or insignificant, indicating an increased probability of being closely held, while post-reform effects are generally negative and highly significant.

\section{Conclusion.}

We have presented a description of almost the entire population of Norwegian corporations in the years 1993-2003. Three logit models have been estimated in order to model the choice of tax regime.

We have found that if the aim is to predict the probability that a specific corporation is closely held, the tax regime in the period prior to the prediction period is more important than the level of profits: If we use the pooled model, our best guess would be that the corporation in question would become widely held, and that would turn out to be correct in slightly more than half the cases. If we instead disregarded the model details and simply predicted that the tax regime in the next 
period would equal the last observed tax regime, we would get a correct prediction in roughly 85 percent of the cases. If we only had pooled cross-section data available, as would correspond to our model 1, this effect would be overlooked.

The high influence of corporation specific effects in the panel data models, indicate that future studies should focus on the owner characteristics of the corporations.

\section{References}

Aarbu, K.O. and T.O. Thoresen (2001): Income Responses to Tax Changes - Evidence from the Norwegian Tax Reform. National Tax Journal 54(2), 319-338.

Alstadsæter, A. (2007): The Achilles Heel of the Dual Income Tax - The Norwegian Case. Finnish Economic Papers 20(1), 5-22.

Burbidge, J.B., L. Magee, and A.L. Robb (1988): Alternative Transformations to Handle Extreme Values of the Dependent Variable. Journal of the American Statistical Association 83, 123-127.

Ayers, B., B. Cloyd, and J. Robinson (1996): Organizational form and taxes: an empirical analysis of small businesses. Journal of the American Taxation Association 18 (supplement), 49-67.

Fjærli, E., and D. Lund (2001). The choice between owner's wages and dividends under the dual income tax, Finnish Economic Papers 14, 104-119.

Gentry, W. (1994): Taxes, financial decisions and organizational form. Evidence from Publicly Traded Partnerships. Journal of Public Economics 53, 223-244.

Fjærli, E. (2004): Tax Reform and the Demand for Debt. International Tax and Public Finance 11(4), 435-468.

Goolsbee, A. (1998): Taxes, organizational form, and the deadweight loss of the corporate income tax. Journal of Public Economics 69, 143-152.

Goolsbee, A. (2004): The impact of the corporate income tax: evidence from state organizational form data. Journal of Public Economics 88, 2283-2299. 
Gordon, R. and J. MacKie-Mason (1994): Tax distortions to the choice of organizational form. Journal of Public Economics 55, 279-306.

Gordon, R. and J. Slemrod (2000): Are "real" responses to taxes simply income shifting between corporate and personal tax base? In: Does Atlas shrug? The economic consequences of taxing the rich. Edt: J. Slemrod. Russel Sage Foundation. Harvard University Press. Ch. 8, 240-288.

Hansson, Å. (2004): Taxpayers Responsiveness to Tax Rate Changes and Implications for the Cost of Taxation. Department of Economics Working Paper No. 5 , Lund University.

Johnson, N.L. (1949): Systems of frequence curves generated by methods of translation. Biometrika 36, 149-176.

Kari, S., H. Karikallio, and J. Pirttilä (2008): Anticipating tax changes: Evidence from the Finnish corporate income tax reform of 2005. Fiscal Studies, forthcoming.

Lambert, P.J. and T.O. Thoresen (2008): Base independence in the analysis of tax policy effects: with an application to Norway 1992-2004. International Tax and Public Finance, forthcoming.

Lindhe, T., J. Södersten and A. Öberg (2004): Economic effects of taxing different organizational forms under the Nordic dual income tax. International Tax and Public Finance 11, 469-485.

MacKie-Mason, J. and R. Gordon (1997): How much do taxes discourage incorporation? Journal of Finance 52(2), 47-505.

Mooij, R.A. de and G. Nicodème (2008): Corporate tax policy and incorporation in the EU. International Tax and Public Finance, forthcoming.

Pirttilä, J., and H. Selin (2006): How Successful is the Dual Income Tax? Evidence from the Finnish Tax Reform of 1993. Department of Economics Working Paper No. 26, November 2006, University of Uppsala.

Romanov, D. (2006): The corporation as a tax shelter: Evidence from recent Israeli tax changes. Journal of Public Economics 90, 1939-1954. 
Selén, J. (2002): Taxable Income Responses to Tax Changes - A Panel Analysis of the 1990/91 Swedish Reform. Trade Union Institute for Economic Research, Working Paper No. 177.

Sørensen, P.B. (1994): From the Global Income Tax to the Dual Income Tax. Recent Tax Reforms in the Nordic Countries. International Tax and Public Finance 1, 57-79.

Sørensen, P.B. (2005): Neutral taxation of shareholder income. International Tax and Public Finance 12, 777-801.

Sørensen, P.B. (2007): Can capital income taxes survive? And should they? CESifo Economic Studies 53(2), 172-228.

Thoresen, T.O. (2004): Reduced Tax Progressivity in Norway in the Nineties: The Effect from Tax Changes. International Tax and Public Finance 11(4), 487506 .

Thoresen, T.O. and A. Alstadsæter (2008): Shifts in organizational form under a dual income tax system. CESifo Working Paper No. 2273.

Weichenrieder, A. (2005): (Why) Do we need Corporate Taxation? CESifo Working Paper No. 1495.

\section{Appendix}


Table 2. Summary statistics and definitions for right-hand side variables *)

\begin{tabular}{lrrl}
\hline & Mean & Std. & Definition \\
\hline Profits & 814.4 & 35673.3 & \\
Aktiva & 19473.2 & 461936.5 & \\
Labor & 9.036 & 90.486 & \\
PROFITS & 2.539 & 5.631 & IHS-transformed value of Profits \\
AKTIVA & 8.111 & 2.041 & IHS-transformed value of Aktiva \\
LABOR & 1.449 & 1.418 & IHS-transformed value of Labor \\
PROFITS^2 & 38.154 & 24.221 & Squared values of PROFITS \\
AKTIVA^2 & 69.954 & 32.202 & Squared values of AKTIVA \\
LABOR^2 & 4.109 & 6.223 & Squared values of LABOR \\
PROFITS*AKTIVA & 23.883 & 51.847 & Product of PROFITS and AKTIVA \\
PAYROLL-1 & 0.813 & 0.390 & Dummy for Payroll zone 1 \\
$\ldots$ & & & $\ldots$ \\
PAYROLL-5 & 0.016 & 0.125 & Dummy for Payroll zone 5 \\
Y-1994 & 0.069 & 0.254 & Dummy for Observation year 1994 \\
$\ldots$ & & & $\ldots$ \\
Y-2002 & 0.128 & 0.334 & Dummy for Observation year 2002 \\
FY-1986 & 0.201 & Dummy for Foundation year 1986 \\
$\ldots$ & 0.042 & & $\ldots$ \\
FY-2002 & & $\ldots .001$ & Dummy for foundation year 2002 \\
NACE-D & 0.000 & 0.316 & Dummy for Manufacturing \\
NACE-F & 0.294 & Dummy for Construction \\
NACE-G & 0.113 & Dummy for Wholesale and retail sale... \\
NACE-I & 0.096 & 0.248 & Dummy for Transport, storage and communication \\
NACE-K & 0.317 & 0.480 & Dummy for Real estate, renting and business activities \\
NACE-N & 0.066 & 0.137 & Dummy for Health and social work \\
NACE-O & 0.359 & Dummy for Other community, social and personal \\
\hline & 0.019 & service activites \\
\hline
\end{tabular}

*) Only variables with names in uppercase are included in regressions. All dummy variables have the value one if an observation meets the requirement indicated by the given definitions; otherwise the value is zero. Some variables are ommitted in order to save space; this is indicated by three dots. 
Table 3. Estimated coefficients in Model 1, pooled logit model for probability of being closely held. $\mathrm{N}=816263$

\begin{tabular}{|c|c|c|c|}
\hline & Coeff. & SE & z-ratio \\
\hline PROFITS^2 & -0.0038 & 0.0002 & -21.68 \\
\hline AKTIVA^2 & -0.0354 & 0.0005 & -74.34 \\
\hline PROFITS*AKTIVA & 0.0048 & 0.0003 & 16.90 \\
\hline PROFITS & -0.0246 & 0.0024 & -10.12 \\
\hline AKTIVA & 0.3600 & 0.0066 & 54.15 \\
\hline $\mathrm{LABOR}^{\wedge} 2$ & -0.1724 & 0.0014 & -120.80 \\
\hline LABOR & 1.0232 & 0.0055 & 184.72 \\
\hline PAYROLL-2 & 0.0598 & 0.0085 & 7.06 \\
\hline PAYROLL-3 & 0.0110 & 0.0281 & 0.39 \\
\hline PAYROLL-4 & 0.0026 & 0.0095 & 0.27 \\
\hline PAYROLL-5 & -0.2362 & 0.0195 & -12.13 \\
\hline FY_1986 & 0.0465 & 0.0127 & 3.67 \\
\hline FY_1987 & 0.0466 & 0.0116 & 4.02 \\
\hline FY_1988 & -0.0211 & 0.0118 & -1.79 \\
\hline FY_1989 & -0.0896 & 0.0111 & -8.07 \\
\hline FY_1990 & -0.1037 & 0.0113 & -9.21 \\
\hline FY_1991 & -0.1126 & 0.0115 & -9.83 \\
\hline FY_1992 & -0.3105 & 0.0116 & -26.85 \\
\hline FY_1993 & -0.2719 & 0.0114 & -23.90 \\
\hline FY_1994 & -0.2844 & 0.0114 & -24.89 \\
\hline FY_1995 & -0.3219 & 0.0120 & -26.74 \\
\hline FY_1996 & -0.3685 & 0.0119 & -30.84 \\
\hline FY_1997 & -0.4947 & 0.0123 & -40.16 \\
\hline FY_1998 & -0.4303 & 0.0126 & -34.21 \\
\hline FY_1999 & -0.4825 & 0.0193 & -24.98 \\
\hline FY_2000 & -0.4707 & 0.0227 & -20.69 \\
\hline FY_2001 & -0.3067 & 0.0357 & -8.60 \\
\hline Y-1995 & -0.1718 & 0.0121 & -14.25 \\
\hline Y-1996 & -0.2236 & 0.0119 & -18.78 \\
\hline Y-1997 & -0.4185 & 0.0118 & -35.43 \\
\hline Y-1998 & -0.4944 & 0.0117 & -42.16 \\
\hline Y-1999 & -0.5407 & 0.0117 & -46.32 \\
\hline$Y-2000$ & -0.4523 & 0.0117 & -38.75 \\
\hline Y-2001 & -0.4302 & 0.0118 & -36.58 \\
\hline Y-2002 & -0.4149 & 0.0119 & -34.91 \\
\hline NACE-D & 0.1427 & 0.0184 & 7.76 \\
\hline NACE-F & 0.6852 & 0.0185 & 37.05 \\
\hline NACE-G & 0.2861 & 0.0174 & 16.46 \\
\hline NACE-I & -0.0446 & 0.0196 & -2.28 \\
\hline NACE-K & -0.1269 & 0.0175 & -7.24 \\
\hline NACE-O & -0.0128 & 0.0217 & -0.59 \\
\hline CONSTANT & -1.2065 & 0.0309 & -39.05 \\
\hline
\end{tabular}


Table 4. Estimated parameters in Models 2 and 3; random effect logit models for the probability of being closely held. $\mathrm{N}=816263$

\begin{tabular}{|c|c|c|c|c|c|c|}
\hline & \multicolumn{3}{|c|}{ Model 2} & \multicolumn{3}{|c|}{ Model 3} \\
\hline & Coeff & SE & z-ratio & Coeff & SE & z-ratio \\
\hline CH_LASTYR ${ }^{1)}$ & & & & 4.5053 & 0.0085 & 530.13 \\
\hline PROFITS^2 & 0.0013 & 0.0004 & 3.42 & -0.0030 & 0.0003 & -10.71 \\
\hline AKTIVA^2 & -0.0668 & 0.0012 & -55.29 & -0.0241 & 0.0007 & -33.71 \\
\hline PROFITS*AKTIVA & 0.0043 & 0.0005 & 7.89 & 0.0043 & 0.0004 & 10.00 \\
\hline PROFITS & -0.0317 & 0.0047 & -6.69 & -0.0361 & 0.0037 & -9.71 \\
\hline AKTIVA & 0.8026 & 0.0165 & 48.66 & 0.2853 & 0.0100 & 28.68 \\
\hline LABOR^2 & -0.2325 & 0.0040 & -57.54 & -0.1192 & 0.0022 & -53.42 \\
\hline LABOR & 1.3877 & 0.0154 & 90.23 & 0.7241 & 0.0091 & 79.37 \\
\hline PAYROLL-2 & 0.3307 & 0.0372 & 8.89 & 0.0154 & 0.0141 & 1.09 \\
\hline PAYROLL-3 & 0.1182 & 0.0737 & 1.60 & -0.0605 & 0.0470 & -1.29 \\
\hline PAYROLL-4 & 0.1054 & 0.0478 & 2.21 & -0.0256 & 0.0156 & -1.63 \\
\hline PAYROLL-5 & -0.4392 & 0.1000 & -4.39 & -0.1328 & 0.0322 & -4.13 \\
\hline FY_1986 & 0.3383 & 0.0755 & 4.48 & 0.0516 & 0.0210 & 2.46 \\
\hline FY_1987 & 0.3504 & 0.0689 & 5.08 & 0.0631 & 0.0193 & 3.27 \\
\hline FY_1988 & 0.2313 & 0.0701 & 3.30 & 0.0230 & 0.0196 & 1.17 \\
\hline FY_1989 & 0.0221 & 0.0657 & 0.34 & 0.0104 & 0.0184 & 0.56 \\
\hline FY_1990 & 0.0390 & 0.0666 & 0.59 & 0.0021 & 0.0187 & 0.12 \\
\hline FY_1991 & -0.0557 & 0.0675 & -0.83 & 0.0316 & 0.0190 & 1.66 \\
\hline FY_1992 & -0.5924 & 0.0670 & -8.84 & -0.0747 & 0.0191 & -3.91 \\
\hline FY_1993 & -0.4133 & 0.0650 & -6.36 & -0.0212 & 0.0188 & -1.13 \\
\hline FY_1994 & -0.5045 & 0.0621 & -8.13 & -0.0509 & 0.0189 & -2.70 \\
\hline FY_1995 & -0.6447 & 0.0614 & -10.51 & -0.0607 & 0.0199 & -3.06 \\
\hline FY_1996 & -0.7734 & 0.0573 & -13.50 & -0.0449 & 0.0197 & -2.27 \\
\hline FY_1997 & -1.1119 & 0.0545 & -20.40 & -0.1171 & 0.0203 & -5.78 \\
\hline FY_1998 & -0.8340 & 0.0532 & -15.68 & 0.0099 & 0.0206 & 0.48 \\
\hline FY_1999 & -0.8609 & 0.0755 & -11.40 & -0.0196 & 0.0314 & -0.62 \\
\hline FY_2000 & -0.4741 & 0.0861 & -5.51 & -0.0811 & 0.0376 & -2.16 \\
\hline FY_2001 & 0.1381 & 0.1225 & 1.13 & -0.0451 & 0.0592 & -0.76 \\
\hline Y-1995 & -0.4179 & 0.0211 & -19.83 & -0.5773 & 0.0197 & -29.28 \\
\hline Y-1996 & -0.5713 & 0.0210 & -27.20 & -0.4056 & 0.0196 & -20.75 \\
\hline Y-1997 & -1.1990 & 0.0211 & -56.88 & -0.9031 & 0.0192 & -46.94 \\
\hline Y-1998 & -1.4719 & 0.0211 & -69.80 & -0.7011 & 0.0193 & -36.42 \\
\hline Y-1999 & -1.6448 & 0.0211 & -77.77 & -0.6494 & 0.0192 & -33.81 \\
\hline Y-2000 & -1.4443 & 0.0212 & -68.26 & -0.3665 & 0.0192 & -19.13 \\
\hline Y-2001 & -1.4149 & 0.0214 & -66.18 & -0.5020 & 0.0194 & -25.88 \\
\hline Y-2002 & -1.4007 & 0.0216 & -64.76 & -0.4998 & 0.0196 & -25.47 \\
\hline NACE-D & -0.1189 & 0.0943 & -1.26 & -0.1119 & 0.0305 & -3.67 \\
\hline NACE-F & 1.4799 & 0.0960 & 15.42 & 0.1664 & 0.0307 & 5.42 \\
\hline NACE-G & 0.3715 & 0.0902 & 4.12 & -0.0211 & 0.0288 & -0.73 \\
\hline NACE-I & -0.9047 & 0.0988 & -9.16 & -0.1760 & 0.0324 & -5.43 \\
\hline NACE-K & -1.2257 & 0.0897 & -13.66 & -0.1748 & 0.0290 & -6.02 \\
\hline NACE-O & -0.3758 & 0.1084 & -3.47 & -0.1780 & 0.0360 & -4.94 \\
\hline CONSTANT & -2.9286 & 0.1116 & -26.25 & -3.1051 & 0.0488 & -63.65 \\
\hline Sigma_u & 4.5664 & 0.0206 & & 0.1906 & 0.0337 & \\
\hline
\end{tabular}

1) CH_LASTYR is a dummy variable, equal to one if the corporation was closely held last year, and equal to zero otherwise. 
Figure 1. Distribution of IHS_Profits

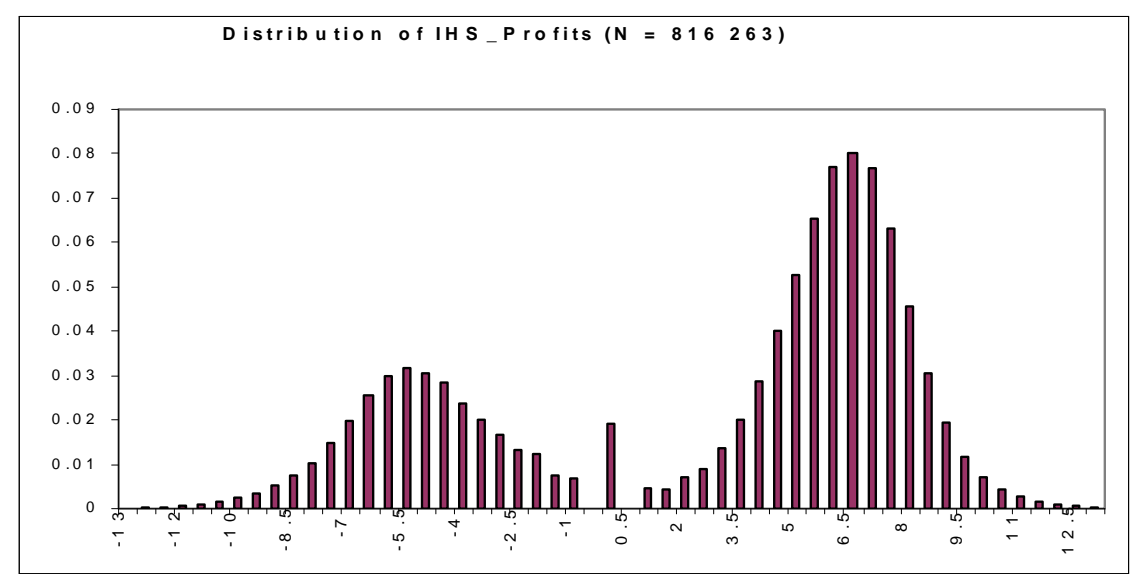

Figure 1b. Share of closely held corporations, by values of IHS-Profits

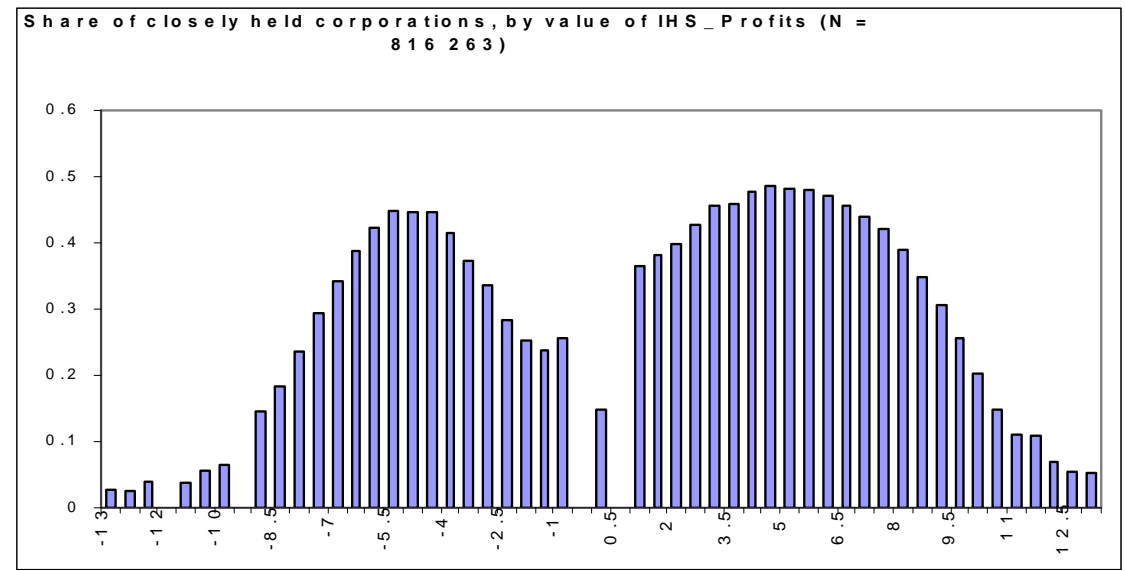


Figure 2. Predicted probability of being closely held as a function of IHS-profits (left) and profits (right). Pooled model
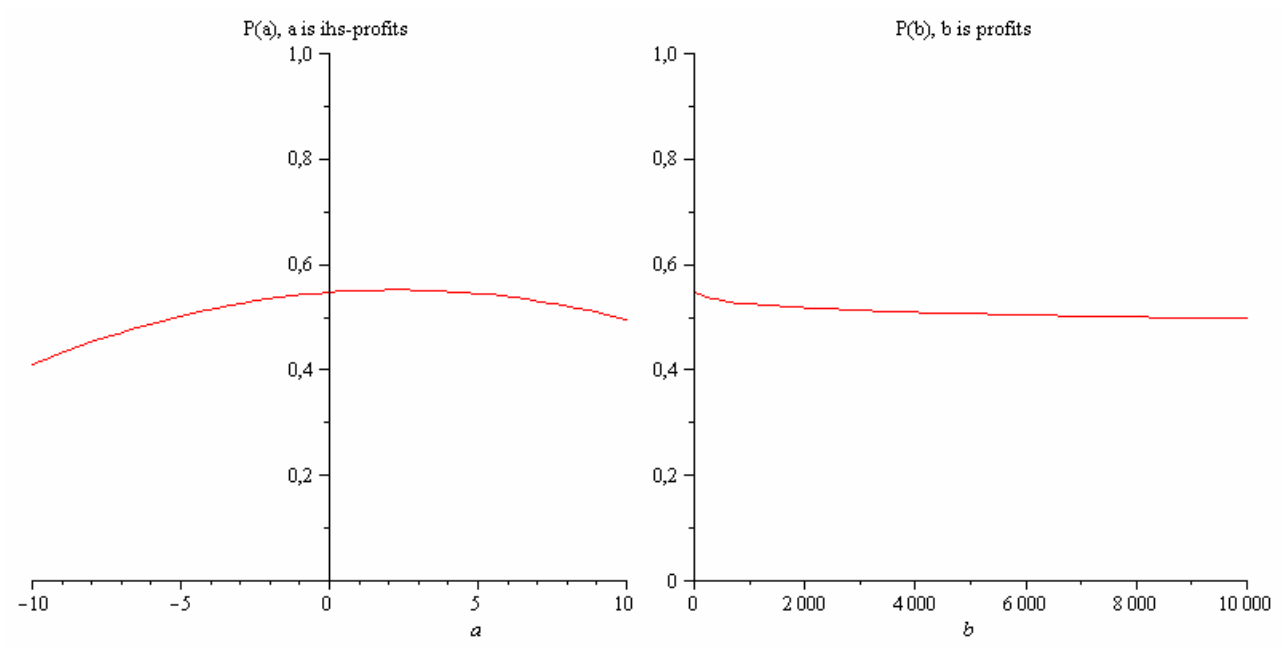

1) In the predictions, AKTIVA and LABOR are set equal to their mean values, FY_1989 and Y-2002 are set unity, while all other dummies are set to zero.

Figure 3. Predicted probability of being closely held as a function of IHS-profits (left) and profits (right). Random effect logit models (Models 2 and 3)
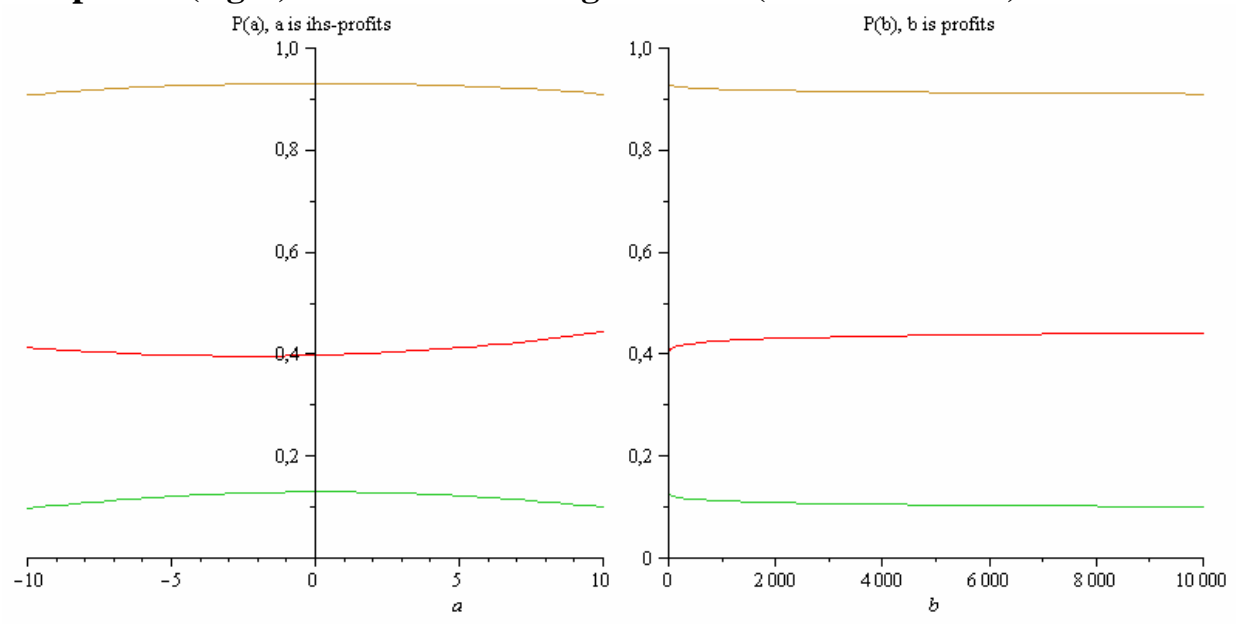

1) Middle curves (red) represent predictions based on Model 2. Upper lines (tan) represents predictions based on Model 3, for corporations that were closely held the previous year, while lower lines (green) represent corporations that where widely held the previous year.

2) The predictions are calculated for the same values of explanatory variables as in Figure 2. In addition it is assumed that $v_{i}=0$. 
Figure 4. Share of closely held corporations for four cohorts, by observation year

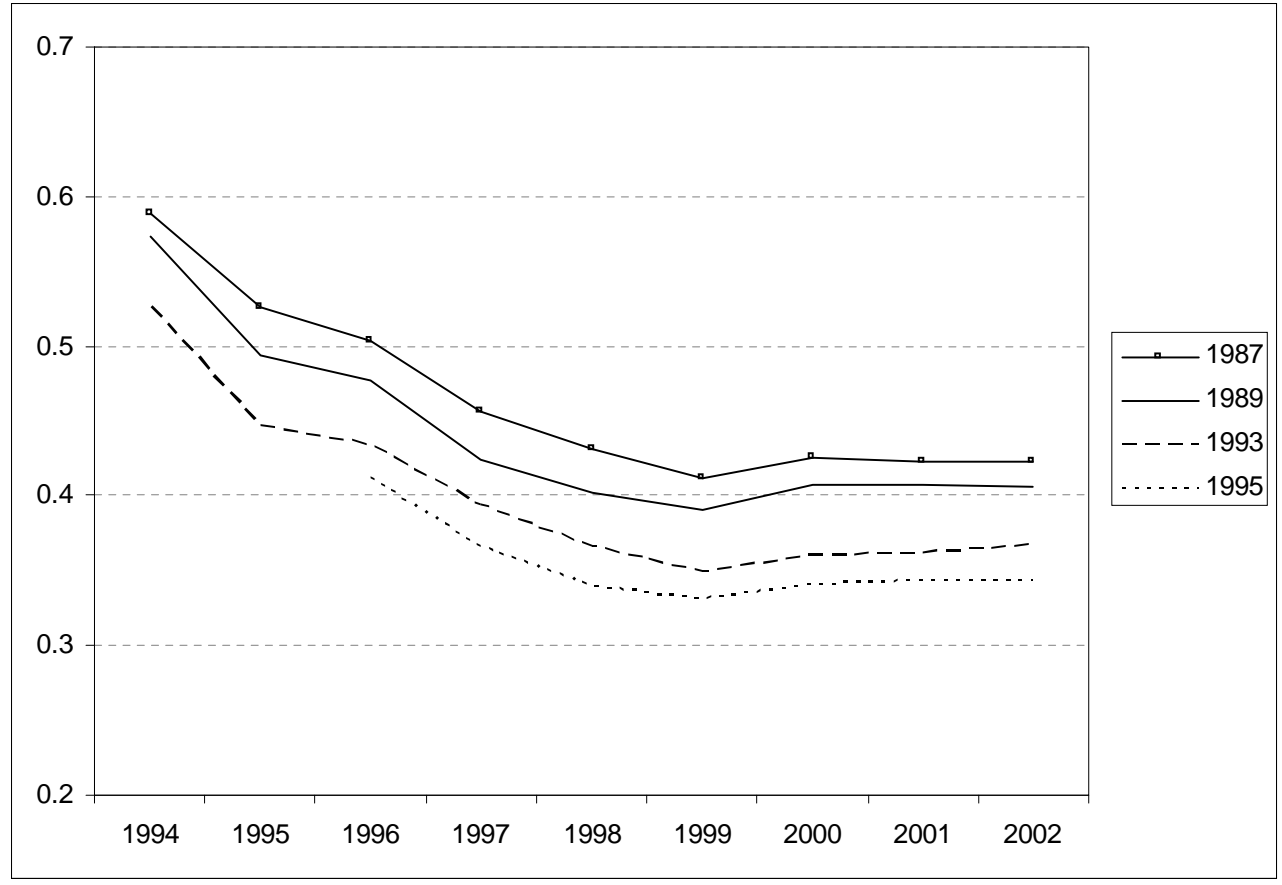




\section{CESifo Working Paper Series}

for full list see www.cesifo-group.org/wp

(address: Poschingerstr. 5, 81679 Munich, Germany, office@cesifo.de)

2329 Paolo M. Panteghini, Corporate Debt, Hybrid Securities and the Effective Tax Rate, June 2008

2330 Guglielmo Maria Caporale, Juncal Cuñado and Luis A. Gil-Alana, Modelling Long-Run Trends and Cycles in Financial Time Series Data, June 2008

2331 Avi Ben-Bassat and Momi Dahan, Social Identity and Voter Turnout, June 2008

2332 Martin R. West and Ludger Wößmann, "Every Catholic Child in a Catholic School”: Historical Resistance to State Schooling, Contemporary Private Competition, and Student Achievement across Countries, June 2008

2333 Erkki Koskela and Panu Poutvaara, Outsourcing and Labor Taxation in Dual Labor Markets, June 2008

2334 Philippe Choné and Laurent Linnemer, Optimal Litigation Strategies with Signaling and Screening, June 2008

2335 Albert Solé-Ollé and Pilar Sorribas-Navarro, Does Partisan Alignment Affect the Electoral Reward of Intergovernmental Transfers?, June 2008

2336 Antonio Cabrales and Piero Gottardi, Markets for Information: Of Inefficient Firewalls and Efficient Monopolies, June 2008

2337 Sumon Majumdar and Sharun W. Mukand, The Leader as Catalyst - on Leadership and the Mechanics of Institutional Change, June 2008

2338 Ulrich Hange, Tax Competition, Elastic Labor Supply, and Growth, June 2008

2339 Guy Laroque and Bernard Salanié, Does Fertility Respond to Financial Incentives?, June 2008

2340 Adriano Paggiaro, Enrico Rettore and Ugo Trivellato, The Effect of Extending the Duration of Eligibility in an Italian Labour Market Programme for Dismissed Workers, June 2008

2341 Helmut Seitz, Minimum Standards, Fixed Costs and Taxing Autonomy of Subnational Governments, June 2008

2342 Robert S. Chirinko, Leo de Haan and Elmer Sterken, Asset Price Shocks, Real Expenditures, and Financial Structure: A Multi-Country Analysis, July 2008

2343 Wolfgang Leininger, Evolutionarily Stable Preferences in Contests, July 2008

2344 Hartmut Egger and Udo Kreickemeier, Fairness, Trade, and Inequality, July 2008 
2345 Ngo Van Long and Bodhisattva Sengupta, Yardstick Competition, Corruption, and Electoral Incentives, July 2008

2346 Florian Baumann, Employment Protection: The Case of Limited Enforceability, July 2008

2347 Alessandro Balestrino, Cinzia Ciardi and Claudio Mammini, On the Causes and Consequences of Divorce, July 2008

2348 Dirk Schindler and Benjamin Weigert, Insuring Educational Risk: Opportunities versus Income, July 2008

2349 Lammertjan Dam and Ben J. Heijdra, The Environmental and Macroeconomic Effects of Socially Responsible Investment, July 2008

2350 Avner Greif, Contract Enforcement and Institutions among the Maghribi Traders: Refuting Edwards and Ogilvie, July 2008

2351 Helmuth Cremer, Philippe De Donder, Dario Maldonado and Pierre Pestieau, Habit Formation and Labor Supply, July 2008

2352 Francesco Menoncin and Paolo M. Panteghini, The Johansson-Samuelson Theorem in General Equilibrium: A Rebuttal, July 2008

2353 Michael Kaganovich and Itzhak Zilcha, Alternative Social Security Systems and Growth, July 2008

2354 Keith Blackburn, Kyriakos C. Neanidis and M. Emranul Haque, Corruption, Seigniorage and Growth: Theory and Evidence, July 2008

2355 Edward Castronova, A Test of the Law of Demand in a Virtual World: Exploring the Petri Dish Approach to Social Science, July 2008

2356 Harald Badinger and Peter Egger, GM Estimation of Higher-Order Spatial Autoregressive Processes in Cross-Section Models with Heteroskedastic Disturbances, July 2008

2357 Wolfgang Buchholz and Jan Schumacher, Discounting the Long-Distant Future: A Simple Explanation for the Weitzman-Gollier-Puzzle, July 2008

2358 Luca Anderlini, Leonardo Felli and Alessandro Riboni, Statute Law or Case Law?, July 2008

2359 Guglielmo Maria Caporale, Davide Ciferri and Alessandro Girardi, Are the Baltic Countries Ready to Adopt the Euro? A Generalised Purchasing Power Parity Approach, July 2008

2360 Erkki Koskela and Ronnie Schöb, Outsourcing of Unionized Firms and the Impacts of Labour Market Policy Reforms, July 2008 
2361 Francisco Alvarez-Cuadrado and Ngo Van Long, A Permanent Income Version of the Relative Income Hypothesis, July 2008

2362 Gabrielle Demange, Robert Fenge and Silke Uebelmesser, Financing Higher Education and Labor Mobility, July 2008

2363 Alessandra Casarico and Alessandro Sommacal, Labor Income Taxation, Human Capital and Growth: The Role of Child Care, August 2008

2364 Antonis Adam, Manthos D. Delis and Pantelis Kammas, Fiscal Decentralization and Public Sector Efficiency: Evidence from OECD Countries, August 2008

2365 Stefan Voigt, The (Economic) Effects of Lay Participation in Courts - A Cross-Country Analysis, August 2008

2366 Tobias König and Andreas Wagener, (Post-)Materialist Attitudes and the Mix of Capital and Labour Taxation, August 2008

2367 Ximing Wu, Andreas Savvides and Thanasis Stengos, The Global Joint Distribution of Income and Health, August 2008

2368 Alejandro Donado and Klaus Wälde, Trade Unions Go Global!, August 2008

2369 Hans Gersbach and Hans Haller, Exit and Power in General Equilibrium, August 2008

2370 Jan P.A.M. Jacobs and Jan-Egbert Sturm, The Information Content of KOF Indicators on Swiss Current Account Data Revisions, August 2008

2371 Oliver Hülsewig, Johannes Mayr and Timo Wollmershäuser, Forecasting Euro Area Real GDP: Optimal Pooling of Information, August 2008

2372 Tigran Poghosyan and Jakob de Haan, Determinants of Cross-Border Bank Acquisitions in Transition Economies: A Latent Class Analysis, August 2008

2373 David Anthoff and Richard S.J. Tol, On International Equity Weights and National Decision Making on Climate Change, August 2008

2374 Florian Englmaier and Arno Schmöller, Reserve Price Formation in Online Auctions, August 2008

2375 Karl Farmer, Birgit Friedl and Andreas Rainer, Effects of Unilateral Climate Policy on Terms of Trade, Capital Accumulation, and Welfare in a World Economy, August 2008

2376 Monika Bütler, Stefan Staubli and Maria Grazia Zito, The Role of the Annuity’s Value on the Decision (Not) to Annuitize: Evidence from a Large Policy Change, August 2008

2377 Inmaculada Martínez-Zarzoso, The Impact of Urbanization on $\mathrm{CO}_{2}$ Emissions: Evidence from Developing Countries, August 2008 
2378 Brian Roberson and Dmitriy Kvasov, The Non-Constant-Sum Colonel Blotto Game, August 2008

2379 Ian Dew-Becker, How Much Sunlight Does it Take to Disinfect a Boardroom? A Short History of Executive Compensation Regulation, August 2008

2380 Cécile Aubert, Oliver Falck and Stephan Heblich, Subsidizing National Champions: An Evolutionary Perspective, August 2008

2381 Sebastian Buhai, Miguel Portela, Coen Teulings and Aico van Vuuren, Returns to Tenure or Seniority?, August 2008

2382 Erkki Koskela and Jan König, Flexible Outsourcing, Profit Sharing and Equilibrium Unemployment, August 2008

2383 Torberg Falch and Justina AV Fischer, Does a Generous Welfare State Crowd out Student Achievement? Panel Data Evidence from International Student Tests, September 2008

2384 Pedro Gomes and François Pouget, Corporate Tax Competition and the Decline of Public Investment, September 2008

2385 Marko Koethenbuerger, How Do Local Governments Decide on Public Policy in Fiscal Federalism? Tax vs. Expenditure Optimization, September 2008

2386 Ronald McKinnon and Gunther Schnabl, China’s Exchange Rate Impasse and the Weak U.S. Dollar, September 2008

2387 Yan-Leung Cheung, Yin-Wong Cheung and Alan T.K. Wan, A High-Low Model of Daily Stock Price Ranges, September 2008

2388 Louis Eeckhoudt and Harris Schlesinger, Changes in Risk and the Demand for Saving, September 2008

2389 Carsten Hefeker and Blandine Zimmer, Uncertainty and Fiscal Policy in an Asymmetric Monetary Union, September 2008

2390 Jay Pil Choi and Byung-Cheol Kim, Net Neutrality and Investment Incentives, September 2008

2391 Marcel Gérard, Financing Bologna, the Internationally Mobile Students in European Higher Education, September 2008

2392 Annette Alstadsæter and Knut Reidar Wangen, Corporations’ Choice of Tax Regime when Transition Costs are Small and Income Shifting Potential is Large, September 2008 